\title{
The Role Of The Supervisory Council Notary Territory In Providing Legal Protection For A Notary Who Have Violated The Law Of The Deed Made
}

\begin{abstract}
Kiki Andriani Samad ${ }^{1}$ and Amin Purnawan ${ }^{2}$
Abstract. The purpose of this study are 1) To clarify the role of the supervisory council notary territory in providing legal protection for a notary who have violated the law of the deed made. 2) To explain the regulatory obstacles and constraints assemblies notary territory in providing legal protection for a notary who have violated the law of the deed made. This research method is a normative juridical research is normative juridical method is the study of writing a good document that we study the norms and principles. Specification used in this study is a descriptive analysis, which is intended to give the data as accurately as possible about a situation or other symptoms. Based on the results of the study concluded thatLegal protection of the Notary, among others in the form of right of refusal, the obligation to reject and exclusive rights when summoned for questioning by investigators, prosecutors or judges, which is subject to approval of Honorary Council of Notaries of Regions as the provisions of Article 66 paragraph (1) of Act No. 22014 which has now been changed to Article 66 paragraph (1) of the Constitution of the Republic of Indonesia Number 2 Of 2014 concerning the Amendment to Act No. 30 of 2004 concerning Notary. Disagreement about the duties and responsibilities as a Council of Trustees Notary region between elements and bustle of every member of both government, notary, and academics to create obstacles during the examination and supervision of technical and administrative poorly in the recording report came from the community often happen, so data on the notary who has not and has been declared missing by the officials working at the Ministry of Justice and Human rights is also one member of the Supervisory Council of notaries, and only the remaining 1 data is still there on the notary who has been in the process by the Supervisory Council of notaries.

Keywords: Regional Supervisory Council; Notary; Legal Protection; Notary; Law Violations; Deeds.
\end{abstract}

\section{Introduction}

The Republic of Indonesia as a constitutional state based on Pancasila and the Constitution of the Republic of Indonesia Of 1945 to ensure certainty, order, and legal protection for every citizen. To ensure certainty, order, and the legal protection required written evidence that is authentic about deeds, agreements, determination, and legal events made before or by the competent authority. ${ }^{3}$

In supporting the success of law enforcement is needed authentic evidence about the circumstances, events, or legal actions are implemented through a certain position by a notary as a public official. Act No. 30 of 2004 concerning Notary has been imposed in lieu of Regulation Notary. ${ }^{4}$

\footnotetext{
${ }^{1}$ Master of Notarial law Students, Faculty of law, Universitas Islam Sultan Agung, email Email: kikiandrianisamad@rocketmail.com

2 Faculty of Law Universitas Islam Sultan Agung

3 M. Luthfan Hadi Darus, 2017, Hukum Notariat dan Tanggung Jawab Jabatan Notaris, Yogyakarta: UII Press, p. 1

4 Endang Purwaningsih, "Penegakan Hukum Jabatan Notaris Dalam Pembuatan Perjanjian Berdasarkan Pancasila Dalam Rangka Kepastian Hukum," on Jurnal ADIL: Jurnal Hukum FH Yarsi, Vol. 2 Nomor 3 (Jakarta, 2011), p 324.
} 
The current globalization era, Notary services in the development process has been increasing as a Notary are certain positions that run profession and legal services to people who need protection and guarantees in order to achieve legal certainty. In General Explanation of Act No. 2 of 2014 concerning Notary, explained that the Constitution of the Republic of Indonesia, the Republic of Indonesia is a state law that guarantees certainty, order and legal protection that core truth and justice. Order and legal protection demanded among other things that the traffic law in public life requires the existence of evidence which clearly define the rights and obligations of a person as a subject of law in society.

An authentic deed as evidence that the strongest and most have an important role in any legal relations in public life, including in business relations, activities in the fields of banking, land, social activities and in the other life needs. The need for written evidence in the form of an authentic deed which clearly defines the rights and obligations, ensure legal certainty and at the same time are also expected to contribute significantly to the settlement cheaply and quickly for the community. Therefore what is stated in the authentic deed must be fully accepted by the parties, unless the interested parties may be able to prove otherwise satisfactorily in the trial court. ${ }^{5}$

The role of the Assembly of Trustees Notary is to carry out surveillance of the Notary, so that in performing his respective duties does not deviate from its authority and did not violate the legislation in force, the functions of the Assembly Supervision of Notaries is that all the rights and powers and duties given to the Notary in performing his respective duties as granted by the legislation in force, is always done on a predetermined path, not only legal, but also on the basis of moral and ethics for the sake of ensuring the legal protection and legal certainty for those who need it. Not less important is the role of the public to oversee and always report the Notary act in carrying out his duties are not in accordance with the applicable law to the local Notary Supervisory Council. With reports such as this can eliminate Notary actions that are inconsistent with the rule of law implementation Notary office tasks.

In the provisions of Article 67 through Article 81 of Notary law (UUJN) there is a means of legal principles for supervising Notary covering behavior and the implementation of the Notary office.

Notary functions inside and outside of the making of the authentic for the first time regulated in Act No. 2 of 2014 On Notary comprehensively. Similarly, the provisions on supervision of Notary conducted by the Assembly of Trustees Notary done by involving academic experts, in addition to departmental duties and responsibilities in the field of notaries as well as the Organization of Notaries, the establishment of the Assembly of Trustees notary in each city or county is intended to improve services and legal protection for public service users Notary.

In Act No. 30 of 2004 concerning Notary set up a new institution called the Supervisory Council, according to Article 1, paragraph 6, the Supervisory Council is a body that has the authority and obligation to implement the guidance and supervision of a notary. The Supervisory Council is to represent the interests of the government to ensure that the notary has done its job correctly and do not harm society. This is a positive breakthrough to ensure the credibility of the notary in the eyes of society and the right of people to get a decent notary services and protected. This is because the Supervisory Council are entitled to receive public complaints about alleged violations of

\footnotetext{
${ }^{5}$ Habib Adjie, 2011, Majelis Pengawas Notaris Sebagai Pejabat Tata Usaha Negara, Cet. 1, Refika Aditama, Bandung, p, 15.
} 
the provisions of Act No. 30 of 2004 concerning Notary Article 70 item g. ${ }^{6}$ Based on the background of the problems that have been raised the problem in this research is formulated as follows: How is the role of the supervisory council notary territory in providing legal protection for a notary who have violated the law of the deed made? And Constraint assembly supervisor notary territory in providing legal protection for a notary who have violated the law of the deed made?

\section{Research methods}

This research is a normative juridical. Specification used in this research is descriptive analytical. Types and sources of data in this research using primary and secondary data. Methods of data collection in this research is the study of literature and field study. Methods of data analysis usingQualitative data analysis.

\section{Discussion}

\subsection{The Role Of The Supervisory Council Notary Territory In Providing Legal Protection For A Notary Who Have Violated The Law Of The Deed Made}

Regarding the authority of Council of Trustees (Local, Regional and Central), there is the authority of the Assembly of Trustees that need to be straightened according to the applicable law, that is, on the report the Assembly Examiner if it finds an offense to conduct an examination of a notary public, assembly supervisor will report to the authorities. According to Article 1 point 24, the Code of Criminal Procedure (Criminal Code) that the report is submitted by a person notices because of rights or obligations under the legislation to the authorities about been or are currently or expected occurrence of criminal events. ${ }^{7}$ Based on the contents of the article, that the requirements to become a complainant, namely: A (one person / individual); and There are rights and obligations under the law.

Supervisory Council is a body with such parameters is associated with the Code of Criminal Procedure Article 1 paragraph 24, that can be the reporter is the subject of law in the form of people, not assemblies or the body. Also related to the decision of the Minister of Justice No. M.01.PW.07.03. 1982 on the Guidelines for the Criminal Procedure Code, in Article 5, paragraph 1 letter a number 1 and Article 7 (1) states that, the investigator and the investigator is obliged to have the authority to receive reports or complaints from anyone about the crime. The substance of this article confirms that the investigator or investigators only received a complaint or report of people. Thus improper Supervisory Council acts as a reporting crime, because the Supervisory Council are not subject to the Law in the form of people.

Notary legal protection against both as a witness, suspect or defendant based UUJN specifically stipulated in Article 66. In the article explicitly states that for the sake of the judicial process, the investigators, the public prosecutor, or the judge who need a photocopy of Minuta Deed and / or letters Minuta attached to the deed or in storage Notary Protocol, must obtain prior approval from the MPD. Furthermore, if the investigator, the public prosecutor, or the judge will call the Notary to be present in the examination relating to a deed made or protocols that are in storage Notary Public, the investigator, the public prosecutor, or the judge should also obtain the approval of the MPD.

\footnotetext{
${ }^{6}$ Central Board Indonesian Notary Association (INI), Editor : Anke Dwi Saputro, 2009, Jati Diri Notaris Indonesia, Dulu, Sekarang, dan Dimasa Mendatang, Gramedia Pustaka, Jakarta,p. 115. 7 Habib Adjie, 2011, Majelis Pengawas Notaris Sebagai Pejabat Tata Usaha Negara, Bandung, Refika Aditama.
} 
Application of Article 66 UUJN a legal corridor in giving approval for action against the pro justicia Notary and to the MPD can use two benchmarks: Approval examination of the Notary as a witness, in terms of the deed of Notary is evidence or facts that are highly relevant to the criminal events that allegedly occurred; and Approval examination of the Notary as a suspect and / or accused can only be provided by the MPD, along Notary concerned first has proven to make mistakes in the execution of his or professionalism by the Supervisory Council decision which is final and binding. ${ }^{8}$

Regarding the form of legal protection of the Notary is an understanding of law enforcement officers on the duties and powers of the Notary and understanding of the law enforcement to know and understand the rules contained in UUJN, where the Notary deed as written evidence that the strongest and most, what is stated in Notary deed must be accepted, unless the parties concerned can prove otherwise by the court decision and binding to the contrary.

Based on an interview with Mr. Sofyan, S. Sos., SH., MH, ${ }^{9}$ as the head office in the region Kemenkumham Kendari city council watchdog role notary region is carrying out surveillance of the Notary, so that in carrying out his duties did not deviate from its authority and did not violate the laws in force. Not less important is the role of the public to oversee and always report the Notary act in carrying out his duties are not in accordance with the applicable law to the local Notary Supervisory Council. With reports such as this can eliminate Notary actions that are inconsistent with the rule of law implementation Notary office tasks.

From the standpoint of the theory of legal protection supervisory role assemblies notary region in Kendari that the presence of justice committed by the MPW, it will provide legal protection and guarantees to the Notary in carrying out his professional manner.

\subsection{Constraint Assembly Supervisor Notary Territory In Providing Legal Protection For A Notary Who Have Violated The Law Of The Deed Made}

Based on the interview with Mr. Sofyan, S. Sos., SH., $\mathrm{MH}^{10}$ is one of the Head of Regional Office based in Kendari, "the Constraints Assembly Supervisory Territory Notaries in providing legal protection for a notary who have violated the law of the deed made is disagreement about the duties and responsibilities as a Council of Trustees Notary region between elements and busy every member of both governments, notaries, and academics to create obstacles during the examination and supervision of technical and administrative poorly in the notes reports came in from the public, concerning their public statements about their deed by notary detrimental to society then the Tribunal Regional supervising directly process the report but if in the process undertaken by the Regional Supervisory Council but if in calling the Regional Supervisory Council is not present, then submitted to the Supervisory Council of the Territory.

Regarding reports from the public regarding the alleged deed by Notary detrimental to society, then the MPD also should hold a session by calling the complainant (the public) and reported (Notary reported). So it will get a clear explanation of the problems that occurred that will ultimately determine the decisions based on these assessments. The reporting mechanism from the public concerning a deed by the

8 Latumeten, Pieter E., 2005, Problematika Kenotariatan: Seputar Masalah Hukum penerapan Pasal 66 UUJN, on Renvoi No. 28, Th. 3, p. 27.

${ }^{9}$ Interview with the Mr. Sofyan, S. Sos., $\mathrm{SH}_{\text {., }} \mathrm{MH}$, as the Head Office of the Regional Kemenkumham in Kendari, on May 23, 2019, 13:15 pm

10 Ibid. 
Notary as stipulated in Article 21 of the Regulation of the Minister of Law and Human Rights M.02.PR.08.10 No. 2004 on Procedures for the Appointment of Members, Termination, Organizational Structure and Work Procedure Procedure examination of the Supervisory Council of Notaries which states that:

- Reports can be filed by parties who feel aggrieved.

- They must be submitted in writing in the Indonesian language accompanied by evidence of which can be accounted for.

- Reports about the alleged violation or breach Notary Code implementation Notary office supervisor submitted to the assembly area.

- Public statements other than those referred to in paragraph 3 submitted to the Supervisory Council of the Territory.

- In the event that the report referred to in paragraph 3 submitted to the Supervisory Council of the Territory, the Territory Supervisory Council transmit to the Regional Supervisory Council authorized.

- In the event that the report referred to in. paragraph 3 submitted to the Central Supervisory Council, the Supervisory Council forwarded it to the Assembly Center Regional Supervising authorities.

- According to the analysis the author in principle, the Supervisory Council is not a super body, but as a builder, pengayomi and protective and try to accompany the Notary, including the status of notaries who are called to be examined as a witness and in such cases there should be essentially to determine Notary concerned as witnesses. For notaries who called is not meaningful or may not be guilty, but there may be other factors that cause Notary concerned as witnesses who may also be a suspect. With the establishment of the Supervisory Council (starting from the local level up to the center), the expected Notary more professional in their duties. This is because the existence of the Supervisory Council for either the local or the central level watchdog and protector and protect the Notary to keep performing its duties in accordance with the provisions of applicable law. So in this case the role of the Supervisory Council of important areas are in addition to provide oversight also provide guidance and protection of the Notary Public for the supervision of the Supervisory Council of the Territory, but when they get to the criminal case had no responsibility MPW anymore, but has become the responsibility of MKN. However, in general a lot of notaries who caught the problem is need for deeper study of causation.

For that we need a reform that starts from within, institutions and organizations who raised the Notary itself. In this case the role of the organization is needed so that the issue does not drag on because it would harm the Notary itself, which ultimately would be detrimental to the public, so as to resolve these problems need the commitment of all the competent authorities in this regard. According to the authors, many cases involving Notaries must be a lesson in order to maintain professional ethics and duties in accordance with the provisions of UUJN.

Thus the legal protection granted by the Supervisory Council of Notaries but not to the person to the Notary office itself, if a legal issue on Notary concerned is not related to the position it is not the authority of the Supervisory Council.

\section{Closing}

\subsection{Conclusion}

- Legal protection of the Notary, among others in the form of right of refusal, the obligation to reject and exclusive rights when summoned for questioning by investigators, prosecutors or judges, which is subject to approval of Honorary 
Council of Notaries of Regions as the provisions of Article 66 paragraph (1) of Act No. 22014 which has now been changed to Article 66 paragraph (1) of the Constitution of the Republic of Indonesia Number 2 Of 2014 concerning the Amendment to Act No. 30 of 2004 concerning Notary.

- Disagreement about the duties and responsibilities as a Council of Trustees Notary region between elements and bustle of every member of both government, notary, and academics to create obstacles during the examination and supervision of technical and administrative poorly in the recording report came from the community often happen, so data on the notary who has not and has been declared missing by the officials working at the Ministry of Justice and Human rights is also one member of the Supervisory Council of notaries, and only the remaining 1 data is still there on the notary who has been in the process by the Supervisory Council of notaries.

\subsection{Suggestion}

- In order to provide legal protection against a Notary, the necessary legal provisions are more clearly linked Notary and legal protection necessary cooperation between the institutions concerned, especially between organizations Indonesian Notary Association (INI) and the Indonesian Police. Both institutions need to make a rule on procedures for summoning and examination Notary Notaries so fixed obtain legal protection in the face of the investigation, prosecution or judicial-related authentic deed made.

- In the face of obstacles by providing a specially to perform supervisory duties, the need for regular meetings every quarter to discuss the performance of each member of the Council of Trustees Notaries Region and the Region, discussed the violation-violation Notary if there are reports from the public, and discussed the work program for 1 (one) year as well as an evaluation of each meeting. And within the constraints of existing funds should be the initiative of MPW and MPD in a request to the government in this case is the Ministry of Justice and Human Rights to issue a decree in respect of dues that have been determined from each notary to assist in MPW and MPD supervision.

\section{Bibliography}

[1] Adjie, Habib, 2011, Majelis Pengawas Notaris Sebagai Pejabat Tata Usaha Negara, Bandung, Refika Aditama.

[2] Endang Purwaningsih, "Penegakan Hukum Jabatan Notaris Dalam Pembuatan Perjanjian Berdasarkan Pancasila Dalam Rangka Kepastian Hukum," Jurnal ADIL: Jurnal Hukum FH Yarsi, Vol. 2 Nomor 3 (Jakarta, 2011),

[3] Habib Adjie, 2011, Majelis Pengawas Notaris Sebagai Pejabat Tata Usaha Negara, Cet. 1, Refika Aditama, Bandung

[4] Latumeten, Pieter E. 2005, Problematika Kenotariatan: Seputar Masalah Hukum penerapan Pasal 66 UUJN, Renvoi No. 28, Th. 3

[5] M. Luthfan Hadi Darus, 2017, Hukum Notariat dan Tanggung Jawab Jabatan Notaris, Yogyakarta: UII Press

[6] Central Board Indonesian Notary Association (INI), Editor : Anke Dwi Saputro, Jati Diri Notaris Indonesia, Dulu, Sekarang, dan Dimasa Mendatang, Gramedia Pustaka, Jakarta, 2009

[7] Interview with the mr. Sofyan, S. Sos., SH., MH, as the Head Office of the Regional Kemenkumham in Kendari, on May 23, 2019, 13:15 pm 